\title{
Nýjar hæfniskröfur til stjórnenda ríkisstofnana
}

\section{Árelía Eydís Guðmundsdóttir, dósent, Viðskiptafræđideild Háskóla Íslands Sólmundur Már Jónsson, sérfræđingur og MS í mannauđsstjórnun}

\section{Útdráttur}

pessi rannsókn bætir við pekkingu á leiðtogum opinberra skipulagsheilda með pví að skoða áhrif nýrrar stjórnunarstefnu. Ný stjórnunarstefna ríkisins var sett fram sumarið 2019. Í henni eru kynntir peir hæfnispættir sem liggja til grundvallar forystu hjá hinu opinbera á Íslandi. Í pessari rannsókn er fjallað um stjórnunarstefnuna, forsendur hennar og innihald til að svara peirri spurningu hvort hún endurspegli starf stjórnenda hjá ríkinu. Einnig er skoðað hvort nýliðar í starfi stjórnenda fái pá pjálfun sem peir telja sig purfa til að geta sinnt starfi sínu miðað við hæfnispættina er tilgreindir eru í stjórnunarstefnunni. Notast var við eigindlega rannsóknaraðferð og tekin djúp viðtöl við tíu nýráðna æðstu stjórnendur hjá ríkisstofnunum. Niðurstöður gefa til kynna að stjórnendum finnst stjórnendastefnan endurspegla starf peirra. Hins vegar er nýliðapjálfun ábótavant og er pví munur á stefnunni og hvernig henni er fylgt eftir, en vegna kórónuveirunnar sem barst til Íslands í febrúar 2020 hefur starfsumhverfi stjórnenda breyst. Praktískt gildi rannsóknarinnar felst í pví að varpa ljósi á raunveruleg viðfangsefni leiðtoga opinberra stofnanna.

Efnisorð: Opinber forysta; opinber stjórnsýsla og stefnumótun; leiðtoga pjálfun. 


\section{STJÓRNSÝSLA}

\section{New skillsets for public leaders}

\section{Abstract}

This research article contributes to leadership in the public sector by investigating the effect of a new policy for public leaders, introduced by Icelandic authorities in the summer of 2019. In the policy, the skillsets that are considered fundamental for public leaders in Iceland were defined. In this article, this policy of public leadership is analyzed, as well as its criteria and context, in order to answer the question if it reflects public leadership in organizations. Also, new leadership training and development is lacking which is not in accordance to the new public policy on leadership. Qualitative data was used and in-depth interviews were conducted with ten new public leaders. The main conclusions indicate that the new public leaders thought that the new public policy was relevant to their work.

However, the participants felt they needed more training and mentoring when they were hired. Thus, there is a difference between the policy and its execution. The Covid-19 epidemic has, of course, dramatically impacted their working environment. The practical value of this research is in shedding a light on real assignments that public leaders face.

Keywords: Public leadership; public leadership policy; leadership development.

\section{Inngangur}

Kröfur til stjórnenda skipulagsheilda um margvíslega hæfni og pekkingu hafa aukist (Funck \& Karlsson 2020; Solomon, Costea \& Nita 2016). Hæfniskröfur jukust umtalsvert hjá hinu opinbera á Íslandi pegar nýskipan í ríkisrekstri var tekin upp um miðjan tíunda áratug síðustu aldar (Ómar H. Kristmundsson 1999). Bylting í stafrænni tækni og alpjóðavæðing setur opinberum leiðtogum nýjar áskoranir (Agarwal 2018). Starfsmenn gera auknar kröfur um stjórnendahæfni (Pórhallur Örn Guðlaugsson, Gylfi Dalmann Aðalsteinsson \& Svala Guðmundsdóttir 2018), leiðtogafærni og hæfni til að leiða 1 teymisvinnu (Chin 2015). Nýir einstaklingar sem valdir eru til forystu purfa leiðsögn um hvernig peir eigi að ná árangri í störfum sínum. Leiðtogar opinberra stofnana leiða stefnumótandi starfsemi samfélaga og pjónustu við borgara. Pví má leiða að pví rök að opinberir stjórnendur purfi að sýna enn meiri aðgát og gagnsæi í störfum sínum (Hartley 2018). Í pessari grein eru leiðtogar skilgreindir sem ,peir sem hafa áhrif til að gera breytingar, stórar eða smáar" (Kellerman \& Webster 2001, 45).

Stjórnendastefna ríkisins var gefin út sumarið 2019, í henni koma fram víðtækar hæfniskröfur til opinberra stjórnenda á Íslandi. Í stjórnendastefnunni eru skilgreindar hæfniskröfur til stjórnenda innan ríkisgeirans. Í pessari grein eru hæfniskröfur til stjórnenda ríkisins, eins og pær birtast í stjórnendastefnunni, greindar og viðhorf nýrra stjórnenda til peirra. Gerð var eigindleg rannsókn með viðtölum við alls tíu forstöðukonur og -menn hjá ríkinu sem tekið hafa til starfa síðustu árin. 


\section{STJÓRNSÝSLA}

Deir nýju stjórnendur sem rætt var við voru valdir með hliðsjón af rannsóknarspurningunni sem er eftirfarandi: Hvað reynir mest á i starfi nýrra stjórnenda bjá rikinu. Til pess að svara peiri spurningu var meðal annars spurt um eftirfarandi pæetti: Fengu nýir stjórnendur fraðslu eða pjálfun pegar störf hófust? Telja nyir stjórnendur að pjälfun sé mikilvag fyrir nýja stjórnendur? Hver eru viðhorf nýrra stjórnenda til hafniskrafna sem fram koma i Stjórnendastefnu ríkisins?

Nýmæli rannsóknarinnar felst í pví að varpa ljósi á stjórnendastefnu ríkisins og kryfja, sem hefur ekki verið gert hingað til. Dessari grein er ætlað að auka pekkingu á stjórnendastefnunni og starfi leiðtoga opinberra skipulagsheilda. Pá er fjallað almennt um hæfniskröfur til stjórnenda ríkisstofnana og um viðhorf forstöðumanna til hæfni og hæfniskrafna. Niðurstöður úr pessari rannsókn geta nýst við innleiðingu stjórnendastefnunnar og par með eflt forystu og stjórnendapjálfun hjá ríkisstofnunum.

\section{Fræðileg umfjöllun}

Rannsóknir á sviði leiðtogafræða eru gerðar frá mismunandi sjónarhorni. Algengustu rannsóknir á sviði forystu innan viðskiptafræða síðustu árin hafa snúist m.a. um umbreytingaforystu, sanna forystu, samspil leiðtoga og fylgjenda, óbeina forystu (e. implicit leadership) og siðræna forystu (Alvesson \& Sveningsson 2003; King 1990; Mintzberg 2009; Yukl 2012; Lee, Chen \& Su 2020).

Rannsóknum á sviði opinberrar forystu hefur vaxið fiskur um hrygg á undanförnum árum. Rannsóknir á stjórnun innan opinbera geirans veita ólík sjónarhorn á forystu prátt fyrir í að í eðli sínu snúist forysta almennt um að leiða hóp að markmiðum eða vera aflvaki breytinga (Hartley 2018; Kellerman 2007, 2013). Hlutverk opinberra stjórnenda er að veita pjónustu og bjargir til borgaranna og pví krefst pað annars konar nálgunar (Kellerman \& Webster 2001). Enn annað sjónarhorn, innan leiðtogafræða er á pólitíska forystu eða leiðtoga (Hartley 2018; Kellerman \& Webster 2001). Hér er sjónum beint að forystu innan hins opinbera geira á Íslandi.

Sumir fræðimenn gera skýran greinarmun á hlutverki stjórnenda og leiðtoga. Mikilvægustu pættir stjórnunar, samkvæmt Kotter (1996) eru skipulagning, rekstur, áætlanagerð, starfsmannamál, stjórnun og að greiða úr vandamálum. Leiðtogi á hinsvegar að sjá um að marka stefnu og móta framtíðarsýn sem veitir innblástur til framkvæmda.

Aðrir gera ekki pennan greinarmun á stjórnun og forystu (Kotterman 2006; Mintzberg \& Gosling 2002). Nýlega hefur Mintzberg ítrekað petta sjónarmið og segir að of mikil áhersla hafi verið lögð á leiðtogann en of lítil á stjórnun (Mintzberg \& Caldwell 2017). Detta er einnig í samræmi við ýmsa fræðimenn sem gera ekki greinarmun á leiðtoga og stjórnanda pó einstök hlutverk megi skilgreina annað hvort sem leiðtogahlutverk eða stjórnunarhlutverk (Alvesson \& Sveningsson 2003; Kotterman 2006).

Bent hefur verið á að stjórnendur hjá hinu opinbera purfi að búa yfir bæði stjórnendafærni og leiðtogafærni (Gylfi Dalmann Aðalsteinsson 2010; Ríkisendurskoðun 2011; Solomon o.fl. 2016). Farsæll stjórnandi parf að hafa til að bera forystuhæfileika og leiðtogi parf að hafa góð tök á stjórnun (Kotterman 2006).

Í pessari grein eru, til einföldunar, notuð orðin stjórnandi og stjórnun hvort sem verið er að fjalla um stjórnendahlutverk eða leiðtogahlutverk. 


\section{STJÓRNSÝSLA}

\subsection{Forysta hjá hinu opinbera}

Nýskipan í ríkisrekstri var innleidd hér á landi um miðjan 10. áratug síðustu aldar og hafði mikil áhrif á breytt hlutverk forstöðumanna og auknar kröfur á hendur peim (Bára Sif Sigurjónsdóttir 2020; Ómar H. Kristmundsson 1999). Nýskipan í ríkisrekstri byggði á pví að nota stjórnunaraðferðir stjórnenda fyrirtækja á almennum markaði. Hugmyndin var að auka skilvirkni, bæta nýtingu fjármuna og pjónustu. Ábyrgð og sjálfstæði forstöðumanna var aukið og ný starfsmannalög nr. 70/1996 voru hvoru tveggja forsendur fyrir bættum rekstri og innleiðingu stefnunnar (Gylfi Dalmann Aðalsteinsson 2005, 2006).

Kröfur opinberra starfsmanna til vinnustaðarins hafa einnig breyst, par með taldar kröfur um aukna pekkingu og hæfni stjórnenda. Opinberir starfsmenn eru margir pekkingarstarfsmenn og peim parf að tryggja krefjandi verkefni og stöðuga áskorun í starfi (Gylfi Dalmann Aðalsteinsson 2010).

Gagnrýnendur nýskipunar í ríkisrekstri hafa sagt að of mikill munur sé á opinberum rekstri og einkarekstri, sem felur í sér að aðferðir í einkarekstrinum henti síður í opinberum rekstri. Hinsvegar hafa rannsóknir leitt í ljós að prátt fyrir eðlismun sé raunar ekki verulegur munur á hlutverki forystufólks hjá hinu opinbera og í einkarekstri. Í einkarekstri gengur starfsemi út á að hámarka arðsemi en hjá hinu opinbera mætti segja að hámarka pjónustu á hagkvæman máta (Boyne 2002).

Í nýrri samantektarrannsókn par sem skoðaðar voru 299 greinar og rannsóknir á 25 ára tímabili um nýskipan í ríkisrekstri kom fram að nýskipan í ríkisrekstri hefur falist að miklu leyti í að bæta stjórnun (Funck \& Karlsson 2020). Pættir eins og árangursmælingar árangursstjórnun, áreiðanleiki, valddreifing og stjórnun hafa verið áberandi í pessum rannsóknum.

Stjórnun hjá hinu opinbera krefst pess að horft sé til margra sjónarmiða. Huga parf að stjórnmálalegum, félagslegum og rekstrarlegum páttum (Gunnar Helgi Kristinsson 2007, 2014; Kellerman \& Webster 2001). Rekstrarlegir pættir eru m.a. hagkvæmni, aukin skilvirkni, mannauðsmál og stefnumótun (Solomon o.fl. 2016).

Stjórnun hjá hinu opinbera hefur breyst frá pví að vera nær eingöngu á herðum æðsta stjórnanda sem nýtir boðvald sitt yfir í samstarf og samvinnu innan stofnana og utan (Chulwoo 2009). Leiðtogar ríkisfyrirtækja purfa að búa yfir félagslegri hæfni og samlíðan, pekkja sjálfa sig, gildi sín og skoðanir og áhrif framkomu sinnar á aðra. Talið er mikilvægt að stjórnendur hafi hæfni til að leiða og taka pátt í teymisvinnu með árangursríkum hætti. Mikilvægi opinna og heiðarlegra samskipti við samstarfsfólk, sem og aðila utan stofnunar hefur aukist (Chin 2015; Kellerman 2013).

Rannsóknir gefa til kynna að nokkur munur sé á afstöðu opinberra starfsmanna og starfsmanna á einkamarkaði. Talið er að peningalegur hvati eða fjárhagslegur ávinningur vegi meira hjá starfsmönnum einkafyrirtækja en opinberra stofnana. Opinberir starfsmenn eru líklegri til að hafa meiri áhuga á samfélagslegu réttlæti, að pjónusta samfélagið og hafa áhrif til góðs (Buelens \& Van den Broeck 2007). Íslensk rannsókn bendir til að vinnustaðamenning sé veikari hjá stofnunum en fyrirtækjum (Pórhallur Örn Guðlaugsson o.fl. 2018). En vinnustaðamenning hefur áhrif á árangur skipulagsheilda og samkvæmt rannsókninni er mestur munur varðandi markmið, framtíðarsýn, teymisvinnu 
og vilja til breytinga. Minnsti munurinn á milli stofnana og fyrirtækja mælist hins vegar varðandi gildi.

Könnunin Stofnun ársins, sem framkvæmd er árlega, sýnir einnig að munur er á viðhorfum starfsmanna á almennum markaði og ríkisstarfsmanna (Sameyki e.d.). Í könnuninni er m.a. spurt um trúverðugleika stjórnenda, starfsanda, launakjör, vinnuskilyrði, sveigjanleika og sjálfstæði í starfi, ímynd stofnunar, ánægju, stolt og jafnrétti. VR gerir sambærilega könnun meðal fyrirtækja á almennum vinnumarkaði. Í öllum pessum páttum koma fyrirtækin á almennum markaði betur út en stofnanirnar. Starfsfólk einkafyrirtækja er ánægðara með laun og ímynd, vinnuskilyrði og sveigjanleiki í starfi og fá einnig áberandi hærri einkunn meðal peirra í könnuninni.

Stjórnendastefna ríkisins gerir kröfur um aukna framleiðni og kallar á betri nýtingu fjármuna og mannauðs, nýsköpun, bætta stjórnun, forgangsröðun, markmiðasetningu og áætlanagerð (Stjórnarráð Íslands 2019). Væntanlega mun ríkið á næstu árum purfa að draga verulega úr útgjöldum til að takast á við skuldasöfnun vegna aðgerða til að mæta áhrifum Covid-19. Mikið mun reyna á stjórnendur og nauðsynlegt að peir búi yfir margs konar hæfni til að takast á við pær áskoranir og kröfur sem til peirra eru gerðar. Í nýlegri rannsókn um hæfniskröfur til forstöðumanna opinberra stofnana kemur hins vegar fram að mjög fátítt er að gerðar séu formlegar lagalegar kröfur um hæfni á sviði stjórnunar, forystu, rekstrar eða fjármála (Bára Sif Sigurjónsdóttir 2020). Stjórnendastefna ríkisins bætir par úr og gerir ítarlegur kröfur um stjórnenda- og leiðtogahæfni.

\section{Stjórnendastefna ríkisins}

Kallað hefur verið eftir sérstakri stjórnendastefnu í fjölda ára eða síðan nýskipan í ríkisrekstri var innleidd (Ómar H. Kristmundsson 1999). Ríkisendurskoðun hefur ítrekað bent á nauðsyn stjórnendastefnu (Ríkisendurskoðun 2011, 2014, 2017a). Í árslok 2016 var krafa um stjórnendastefnu lögfest með breytingu á starfsmannalögum nr. 70/1996. Stjórnendastefnan var sampykkt í júní 2019 (Stjórnarráð Íslands 2019b). Stjórnendastefnan er skýr en jafnframt mjög ítarleg. Stefnan hefst á eftirfarandi orðum:

Starfsfólk ríkisins gegnir lykilhlutverki í opinberri pjónustu. Stjórnendur purfa að búa yfir hæfni og pekkingu til að geta brugðist við og haft frumkvæði að breytingum í samfélaginu og sífellt flóknara starfsumhverfi (Stjórnarráx Íslands 2019b, 3).

Kjarni stefnunnar felst í hæfni og pekkingu til að geta brugðist við og haft frumkvæði í breytilegum heimi og er í góðu samræmi við fræðilega umfjöllun um auknar kröfur til stjórnenda stofnana. Stefnan byggir á skýrum markmiðum og framtíðarsýn:

Stjórnendur ríkisins ganga fram með góðu fordæmi og hafa frumkvæði að betri og skilvirkari pjónustu við samfélagið. Starfsumhverfið er nærandi og einkennist af samvinnu og samstarfi par sem styrkleikar fá notið sín. Stjórnsýslan er opin og gagnsæ. Skýr tenging er milli ráð- 
stöfunar fjármuna og ávinnings fyrir samfélagið. Öll starfsemi ríkisins miðar að bættum lífskjörum á Íslandi (Stjórnarráð Íslands 2019b, 3).

Í stefnunni er fjallað bæði um pætti sem hefðbundið geta fallið undir leiðtogahlutverkið og aðra sem falla frekar undir stjórnendahlutverkið. Má til dæmis nefna framsýni, stefnumótun og forystu sem falla undir leiðtogahlutverkið. Áætlanagerð, skilvirk stýring verkefna og hagkvæmni í rekstri mætti hins vegar kalla hefðbundin stjórnunarhlutverk. Petta er í samræmi við umfjöllun hér að framan um að nauðsynlegt sé að kunna skil á báðum hlutverkum (Kotterman 2006; Mintzberg 2009).

Stjórnendastefnan er heildstæð stefna sem fjallar um ráðningarferli, starfskjör, heilsu og vellíðan, stjórnendasamtal og endurgjöf, starfspróun og starfslok (mynd 1). Grunnur stefnunnar og miðja hvílir á að stjórnandinn sýni heilindi í starfi.

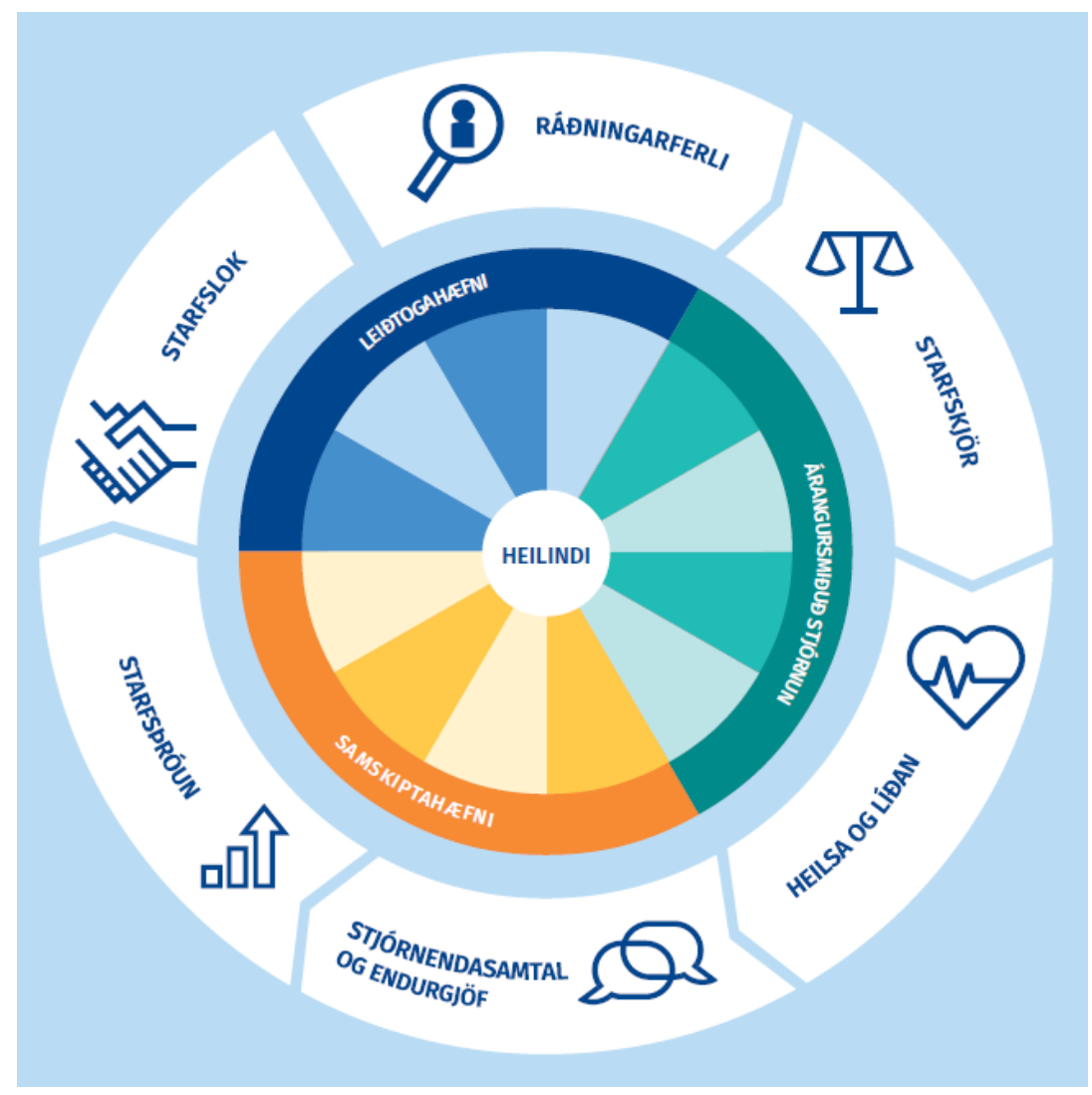

Mynd 1. Stjórnendastefna ríkisins (Stjórnarráđ Íslands, 2019b, 6)

Í pessari rannsókn er sjónum beint að hæfniskröfunum sem eru undirflokkar stjórnendastefnunnar, sem gerðar eru til stjórnenda ríkisstofnana. Hæfniskröfurnar koma skýrt fram í svokallaðri kjörmynd stjórnenda sem sjá má á mynd 2. 


\subsection{Hæfnispættir í stjórnendastefnu ríkisins}

Leiðtogahæfni, samskiptahæfni og árangursmiðuð stjórnun eru peir hæfnispættir sem lagðir eru til grundvallar. Hver peirra skiptist í fjóra undirpætti (sjá mynd 2).

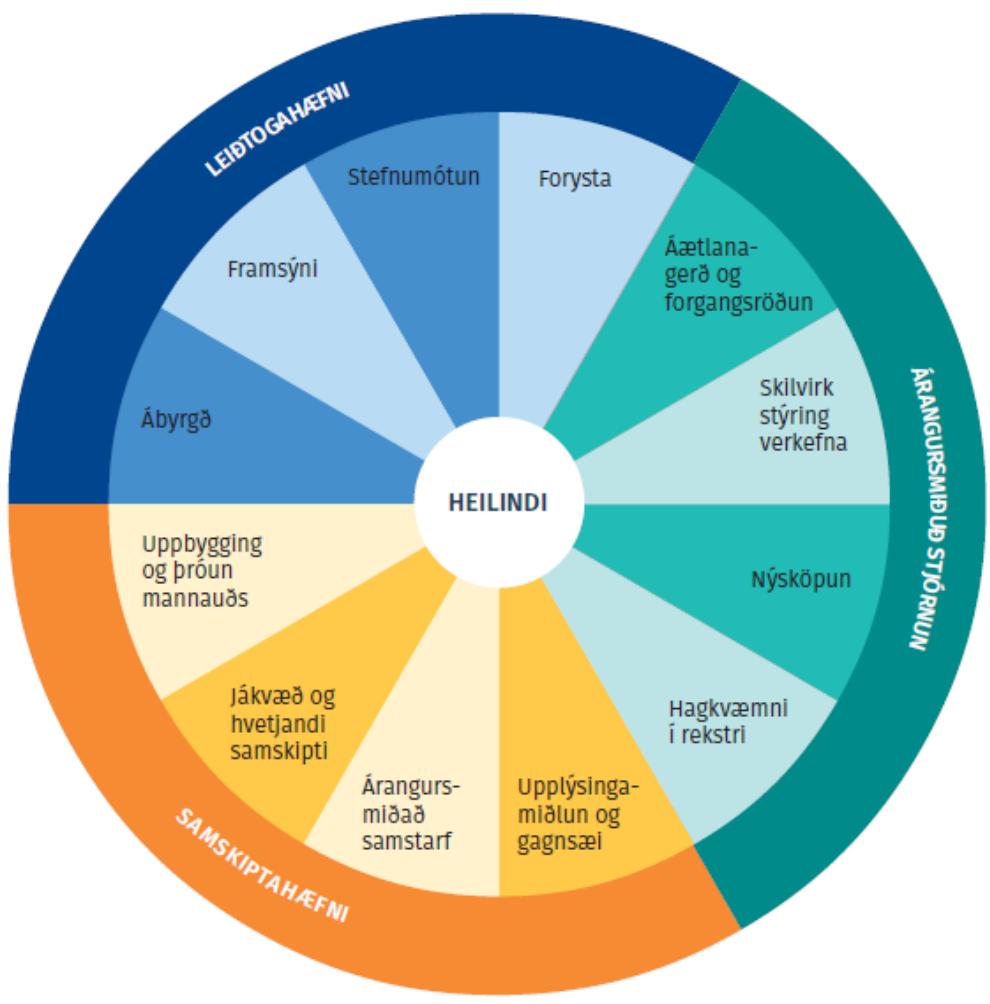

Mynd 2. Kjörmynd stjórnenda (Stjórnarráđ Íslands 2019b, 4)

Eins og fyrr segir grundvallast hæfnispættirnir á pví að stjórnandinn sýni heilindi í starfi. Heilindi, traust og auðmýkt koma víða fyrir í leiðtogafræðum og er petta í samræmi við pað (Palanski \& Yammarino 2007). Opinberir stjórnendur bera ábyrgð á pjónustu ríkisvaldsins til pegnanna og pví er mikilvægi heilinda og gagnsæis talið enn brýnna (Kellerman \& Webster 2001). Heilindi í starfi eru í stjórnendastefnu ríkisins skilgreind á eftirfarandi hátt:

Hefur hag samfélagsins ávallt að leiðarljósi. Ávinnur sér traust stjórnvalda, samfélagsins, samstarfsfólks og samstarfsaðila, er háttvís í framkomu og samskiptum. Er framtakssamur/-söm og fylgir verkefnum eftir frá upphafi til enda (Stjórnarrád Íslands 2019b, 5). 
Lögð er áhersla á hag samfélagsins og traust. Hvort tveggja vísar til forystuhæfni stjórnandans. Stjórnendum er gert að vera háttvís í framkomu og samskiptum, sem vísar til samskiptahæfninnar. Að síðustu segir að stjórnandinn sé framtaksamur/ -söm sem vísar til priðja páttarins; árangursmiðaðrar stjórnunar.

Síðan stefnan var gefin út hefur, undir forystu fjármála- og efnahagsráðuneytisins í samvinnu við forstöðumenn og ráðgjafa, verið unnið að nánari skilgreiningum hæfniviðmiða, útfærslum og innleiðingu.

Hér er að neðan er fjallað stuttlega um hæfniviðmiðin.

Hæfniviðmið fyrir heilindi eru skilgreind pannig að stjórnandi sé heill og óskiptur í störfum sínum og hafi til að bera: Heiðarleika, hugrekki, sjálfspekkingu og úthald.

Heilindi vega jafnt í öllum forstöðumannsstörfum óháð pví hvort stjórnun sé stór hluti af starfinu eða ekki enda byggjast aðrir pættir á peim.

Í stjórnendastefnunni er leiðtogahæfni brotin niður í fjóra pætti; ábyrgð, framsýni, stefnumótun og forystu. Skilgreiningin á ábyrgð er að stjórnandinn sýni ábyrgð í verki og stuðli að öflugri liðsheild. Með framsýni er átt við að stjórnandinn meti stöðuna hverju sinni, horfi til framtíðar og komi auga á tækifæri og áskoranir í starfseminni. Stjórnandi eigi að gera ráðstafanir og takast á við framtíðarverkefni í síbreytilegu umhverfi.

Stefnumótun er skilgreind pannig að forstöðumaður móti metnaðarfulla framtíðarsýn og marki leiðina pangað með stefnumótandi áætlunum í samræmi við áherslur ráðherra.

Með forystu er átt við að forstöðumaður sé í fararbroddi á sínu fagsviði, sýni frumkvæði og hafi lag á að fá samstarfsfólk og aðra samstarfsaðila til liðs við sig.

Í stjórnendastefnunni eru fjórir hæfnispættir skilgreindir varðandi samskipti; uppbygging og próun mannauðs, jákvæð og hvetjandi samskipti, árangursmiðað samstarf og upplýsingamiðlun og gagnsæi.

Uppbygging og próun mannauðs felst í pjálfun starfsfólks með pað að markmiði að pað öðlist pekkingu og sjálfstraust til að ná árangri í starfi. Forysta snýst um að taka eftir hæfileikum starfsfólks, veita pví umboð til athafna, veita góðri frammistöðu athygli og taka á slakri frammistöðu.

Jákvæð og hvetjandi samskipti eru skilgreind pannig að forysta skapi jákvæða menningu á vinnustaðnum sem hafi hvetjandi áhrif, forstöðumaður sé góð fyrirmynd og tryggi góð samskipti við notendur og samstarfsaðila með skýrum leiðbeiningum.

priðja samskiptahæfni er árangursmiðað samstarf, sem skilgreinir mikilvæga samstarfsaðila, bæði innan og utan ríkiskerfisins. Stjórnandinn skal efla samstarf við pá meðal annars með pað að markmiði að fá yfirsýn yfir pað sem er að gerast á viðkomandi fagsviði.

Með upplýsingamiðlun og gagnsæi ber forstöðumanni að tryggja öflugt upplýsingaflæði bæði inn á við og út á við. Hann skal viðhafa gagnsæi í ákvarðanatöku og hafa viðeigandi gögn aðgengileg. Pessi skilgreining helst í hendur við kröfur sem lög og reglur gera til stjórnenda um vandaða stjórnsýslu. 
Síðasta lykilhæfnin í stjórnendastefnunni er pekking, hæfni og kunnátta í árangursmiðadri stjórnun. Eins og með hina lykilpættina tvo er henni skipt upp í fjóra hæfnispætti; áætlanagerð og forgangsröðun, skilvirk stýring verkefna, nýsköpun og að lokum hagkvæmni í rekstri.

Árangursmiðuð stjórnun hvílir á góðri áætlanagerð og forgangsröðun, ekki síst í opinberum rekstri par sem skattfé og fjárveitingar eru takmarkaðar (Ríkisendurskoðun 2011). Forstöðumaður skal festa í sessi ferli áætlanagerðar sem tekur mið af gildandi stefnu og leggja skal áherslu á að ná settum markmiðum. Forstöðumaður parf taka erfiðar ákvarðanir um forgangsröðun pannig að markmið náist. Áætlanagerðin tekur mið af stefnu og framtíðarsýn.

Skilvirk stýring verkefna felst í pví að stjórnendur að tryggi skilvirka framkvæmd áætlana með viðeigandi aðferðafræði við stjórnun verkefna og fylgi eftir innleiðingu peirra.

Nýsköpun er fjórði hæfnispátturinn og skal stjórnandi sýna frumkvæði og skapa hvata til nýsköpunar til að finna nýjar leiðir til að leysa verkefni og bæta pjónustu (Stjórnarráð Íslands 2019).

\subsection{Starfspróun og nýliđapjálfun stjórnenda}

Hæfnispættirnir tólf eru fjölbreyttir og ekki hægt að gera ráð fyrir að stjórnandi sé jafnvígur á pá alla enda gerir stjórnendastefnan ráð fyrir starfspróun til að efla pá og bæta.

Algengt er að líta svo á að ekki sé hægt að búa til stjórnanda í kennslustofunni en hægt sé að bæta hæfni stjórnenda með pjálfun og námi (Mintzberg \& Gosling 2002).

Starfspróunaráxtlun fyrir hvern stjórnanda skal byggja á niðurstöðu starfs- og hæfnigreiningar, taka mið af starfsemi og markmiðum stofnunar og málaflokks og reynslu og áhugasviði stjórnandans. Lögð er áhersla á fræðslu og móttöku nýrra stjórnenda til að peir geti frá upphafi sinnt starfi sínu af fagmennsku. Með stefnunni er viðurkennt að stjórnendur koma ekki fullskapaðir til starfa og að peir purfi endurmenntun og pjálfun til að bæta og auka við hæfni sína rétt eins og aðrir starfsmenn, bæði í upphafi starfsferilsins en einnig jafnt og pétt á starfstímanum. Kröfur hafa verið að breytast varðandi ráðningarferli forstöðumanna hjá ríkinu og er pað í heildina orðið vandaðra en áður (Berglind Möller \& Gylfi Dalmann Aðalsteinsson 2014; Hafsteinn Dór Hauksson \& Ómar H. Kristmundsson 2019).

\section{Aðferðir og gögn}

Rannsókn pessi miðar að pví að kanna hvað reynir mest á í starfi forstöðukvenna og -manna, viðhorf peirra til Stjórnendastefnu ríkisins og til peirra hæfniskrafna sem par koma fram. Rannsóknin var unnin í samstarfi við Kjara- og mannauðssýslu ríkisins sem fer með miðlæg mannauðsmál hjá ríkinu. Til að ná sem dýpstum skilningi á viðfangsefninu var ákveðið að taka djúp-viðtöl við forstöðumenn og pví er um eigindlega rannsókn að ræða. Túlkun niðurstaðna byggir á pví að túlka orð, orðræðu og hegðun í viðtölunum en ekki tölulegar upplýsingar (Bell, Bryman \& Harley 2018). Ekki er hægt að alhæfa út frá gögnunum en pau gefa vísbendingar. 
Ákveðið var að einskorða rannsóknina við forstöðumenn sem nýlega hafa tekið til starfa. Alls hafa 40 manns hafið störf sem forstöðumenn á árunum 2017 - 2020, 27 konur eða 67,5\% og 13 karlar eða 32,5\%. Ákveðið var að taka tíu manns í viðtöl og leitast var við að hafa sem mesta fjölbreytni hvað varðar tegund stofnana, stærð, staðsetningu og jafnframt var lögð áhersla á að pær tilheyri mismunandi ráduneytum.

Fjórum körlum og sex konum var boðin pátttaka og sampykktu allir sem fengu boð að taka pátt. Viðtölin fóru fram í nóvember og desember 2020 á fjarskiptaforitinu Microsoft Teams sem auðveldaði að taka viðtöl við stjórnendur út um allt land. Viðmælendur eru á aldursbilinu fertugs til sextugs og höfðu allir nema einn stjórnunarreynslu áður en peir tóku við forstöðumannsstarfi. Allir voru áður starfandi hjá hinu opinbera nema einn sem var starfandi í einkarekstri. Sex af pessum tíu forstöðumönnum voru áður millistjórnendur í sömu stofnun og peir nú leiða.

Við úrvinnslu á gögnum var notast við opna kóðun en hún byggir á pví að greina viðtölin kerfisbundið og skipulega til að finna og skilgreina sameiginleg pemu (Corbin \& Strauss 2014). Fyrir sakir nafnleyndar er ekki notast við raunveruleg nöfn viðmælenda, heldur er peim gefin einhver af algengustu eiginnöfnum á Íslandi samkvæmt skrá Hagstofu Íslands (Hagstofa Íslands e.d.).

Í rannsókninni var lagt upp með fjögur pemu auk bakgrunnsspurninga: Starfið og árangursríkar aðferðir, ráðningarferlið og hæfniskröfur, nýliðapjálfun forstöðumanna, Stjórnendastefna ríkisins og hæfniskröfur. Við greiningu viðtalanna bættust við tvö pemu í viðbót: Samskipti við fagráðuneyti og ráðleggingar til nýrra forstöðumanna.

Dæmi um spurningar: Ef pú ættir að lýsa starfinu í nokkrum orðum, hvað kemur fyrst í hugann? Hvað reynir mest á í starfinu (að slepptu covid)? Hvaða hæfnispætti telur pú mikilvægasta fyrir starfið - nefndu 3 - 5 pætti? Telur pú einhverja hæfnispætti vanta í kjörmynd stjórnenda?

Tafla 1. Listi yfir viðmælendur

\begin{tabular}{|l|c|c|}
\hline Nafn & Fæđingarár & Stjórnunarreynsla \\
\hline Guđrún & Fyrir 1970 & Já \\
\hline Anna & Fyrir 1970 & Já \\
\hline Kristín & 1970 eđa síðar & Já \\
\hline Sigríður & 1970 eđa síðar & Já \\
\hline Jón & 1970 eđa síđar & Neí \\
\hline Sigurður & Fyrir 1970 & Já \\
\hline Guđomundur & Fyrir 1970 & Já \\
\hline Gunnar & Fyrir 1970 & Já \\
\hline Margrét & Fyrir 1970 & Já \\
\hline Helga & Fyrir 1970 & Já \\
\hline
\end{tabular}




\section{Niðurstöður}

Greining á viðtölunum leiddi í ljós fjölmörg atriði sem viðmælendur voru sammála um eða höfðu svipuð viðhorf. Í raun má segja að viðhorf peirra og reynsla séu á heildina litið mjög lík pó eðlilega sé ýmislegt frábrugðið og persónubundið. Viðmælendur voru allir mjög meðvitaðir um pjónustuhlutverk hins opinbera.

Opinber rekstur snýst um að veita pjónustu og pjónustuhlutverkið kom fram í mörgum viðtölunum sem sýnir að pað er hugleikið forstöðumönnunum. Рað er í samræmi við framtíðarsýn og markmið stjórnendastefnunnar. Helga er dæmigerð hvað petta varðar í svörum sínum:

Đað gerist ekkert án pess [starfsfólksins] og náttúrulega einkennir líka opinberan rekstur mjög mikið að pað er mjög oft sem að starfsemin er fólgin í að veita pjónustu. Og petta er hlutverk sem að má bara ekki missa sjónar á.

Gunnar tekur í sama streng. :

... alltaf pegar maður er að velta einhverju fyrir sér, pá er alltaf lokaspurningin, hvernig... er petta til góðs fyrir [borgarann], eða gagnast petta peim? Skilurðu mig? Dað er alltaf lokaspurningin hjá mér í öllu.

\subsection{Lýsing á starfi og væntingar - „pað eltir ein áskorun aðra“}

Starf forstöðumanna er að mati viðmælenda skemmtilegt og krefjandi. Verkefnin eru fjölbreytt. Margir viðmælendur nefna pörf á pví að hafa yfirsýn. Í viðtölunum kom fram að pau eru mjög áhugasöm og hafa mikinn drifkraft og metnað gagnvart starfinu. Jón lýsir starfinu með eftirfarandi hætti:

Раð er mikið at og í mörg horn að líta en skemmtilegt, gríðarlega skemmtilegt og gefandi starf pó að pað sé stundum hérna... pó að pað sé mikið álag sko. petta er mjög verðugt.

Margrét lýsir starfinu og væntingum á eftirfarandi hátt:

Petta er mikið starf og ég áttaði mig alveg á pví áður en ég kom til starfa en pað kemur mér skemmtilega á óvart hvað mér finnst petta gefandi og spennandi... en álag í mínum huga er aldrei eitthvað fráhrindandi. Álag getur alveg verið jákvætt.

Anna lýsir helstu páttum í starfinu:

Petta er svona eftirfylgni, samskipti, stefnumótun. Svona, petta eru svona fyrstu prjú orðin sem að mér dettur í hug... Баð eltir ein áskorunin aðra en maður tekst bara á við pað. 
Sigríður stýrir lítilli stofnun og gengur í öll verk, bæði af pví hún er tilneydd til pess en einnig meðvitað til að vera í góðum tengslum við verkefnin og starfsfólkið. Hún lýsir vel peim fjölbreyttu verkefnu sem forstöðumenn purfa að geta leyst:

Ég parf að vera að innleiða jafnlaunavottun, ég er að innleiða betri vinnutíma, pað eru Græn skref í ríkisrekstri [umhverfisátak ríkisins] og pað er petta og petta og petta og svo á ég að vera að sinna starfinu mínu og ég er að grípa inn í og ég stekk og afgreiði fólk ef að pað vantar...

\subsection{Helstu verkefni}

Mikill samhljómur er meðal viðmælenda um að starfsmannamál geti reynt mikið á. Einnig kemur fram hjá mörgum að reksturinn sé krefjandi og hjá nokkrum að fjármagn sé af skornum skammti. Meirihluti stofnananna hafði nýlega farið í gegnum sameiningar eða viðamiklar skipulagsbreytingar. Viðmælendur voru á einu máli um að skipulagsbreytingar, mótun framtíðarsýnar og stefnu er krefjandi en jafnframt gefandi og spennandi.

\subsubsection{Starfsmannamál - „petta getur tekið á“}

Starfsmannamál og samskipti eru ofarlega á baugi hjá viðmælendum. Viðmælendur nefndu allir að samskipti væru grundvallarpáttur í starfi peirra og par á meðal lausn ágreiningsmála.

Kristín telur starfsmannamálin vera erfiðustu málin:

Ég held að erfið starfsmannamál, pau eru alltaf pað erfiðasta sem maður tekst á við.

Guðmundur nefnir sérstaklega úrlausn ágreiningsmála:

Ja, mér finnst alltaf starfsmannamálin erfið. Ef að pað koma einhver, hvað á ég að segja, ef að pað kemur upp ágreiningur á milli [starfsmanna]. Og menn eru ekki sammála um aðferðirnar að markmiðunum að pá... petta getur tekið á og ég hef alltaf lagt áherslu á að miðla málum dálítið.

Starfsmannamálin eru krefjandi að mati Guðrúnar, ekki síst í tengslum við stöðuga hagræðingarkröfu. Pá er mikilvægt að hafa gott samstarfsfólk:

Mannauðsmálin eru alltaf viðkvæmustu málin, mesta áskorunin í pessum flóknari, pví pað er náttúrulega bara manneskjan og pað er vandmeðfarið en pað sem hjálpar auðvitað er að hafa gott fólk með sér eins og mannauðsstjóra og góða ráðgjöf... 


\subsubsection{Krefjandi rekstur - „parft ad vera sérfradingur á svo mörgum sviðum"}

Viðmælendur voru sammála um að rekstrarmál gæu verið erfið og skortur á fjármagni og sérhæfðu starfsfólki. Allir forstöðumennirnir nefna að pau purfa að sinna mörgum, fjölbreyttum og oft sérhæfðum verkefnum. Jón segir:

Prátt fyrir stærð, eða kannski vegna stærðar stofnunarinnar að pá er samt sko stjórnunarlagið frekar veikt sem helgast af pví að langflestir stjórnendurnir hafa [faglega] vinnu meðfram sem að oft tekur yfir... og fyrir svona stóra stofnun að pá gerir pað að verkum að pað eru bara svolítið mörg verkefni sem að fara á forstjóra bara af pví að pau gerast ekki annars staðar.

Sigríður er forstöðukona yfir stofnun sem gekk í gegnum sameiningarferli par sem nokkrar stofnanir runnu saman:

... pað sem hefur verið áskorun er að við höfum verið fjársveltar stofnanir... pegar embættið var sett á laggirnar pá áttum við ekki fyrir launum og húsnæði, hvað pá eitthvað annað.

Guðmundur nefnir nýjar kröfur og verkefni:

Svo finnst mér líka, pað er alltaf verið að setja æ meiri kröfur og verkefni á stjórnendur ríkisstofnana... petta eru svona auknar kvaðir pannig að pað er svona í ótrúlega mörg horn að líta. Dú parft að vera sérfræðingur á svo mörgum sviðum.

\subsubsection{Framtið arsýn, sameiginleg stefna - „petta snýst nú um eiginlega finnst mér um leiðtogablutverkið “} Flestar stofnanirnar hafa farið í gegnum skipulagsbreytingar og bví hefur verið stór hluti af verkefnum forstöðumannanna að móta framtíðarsýn og stefnu. Margrét stýrir stórri stofnun með dreifða starfsemi sem hefur verið sameinuð:

En pað sem að reynir á mest hérna pað er að svona búa til eina heild... að fá fólkið til pess að horfa á sig sem einn vinnustað og svona sem sameiginlegt teymi... Ég hef fengið stjórnendur til pess að vinna að með mér núna í framtíðarstefnu og starfsáætlun fyrir næsta ár... par fann ég svona að fólk virkilega sá ávinninginn í pví að vera með sömu sýn og kannski stefna í sömu áttir.

Stefnumótun, sem hefur líka verið eitt af stóru verkefnunum hjá Önnu, tengist starfsmannamálum náið:

... ég held að pað sé nú kannski pessi starfsmannamál sem að hefur verið áherslan petta fyrsta ár og okkur tókst að breyta öllu skipurit- 
inu... meira en helmingur starfsmanna fengu nýjan fagstjóra eða fór á nýtt svið pannig að við gerðum svolítið miklar breytingar sem að komu bara mjög vel út úr könnuninni [Stofnun ársins].

Helga fjallar um alla pessa prjá pætti, starfsmannamál, erfiðan opinberan rekstur og mótun framtíðarsýnar:

... og er eitt af rosa stóru hlutverkum forstjóra finnst mér, pað er að gæta pess að pað sé ekki verið að sóa peningum neins staðar. En síðan er pað náttúrulega að reyna að ná fólki með sér. Svona reyna að fylla pað eldmóði og fá pað með sér til góðra verka. Petta snýst nú um... petta snýst nú um eiginlega finnst mér leiðtogahlutverk.

\subsection{Aðferðir og hæfni í stjórnun og forystu - „meginlínan hjá mér er að petta er samstarf"}

Sérstaklega var spurt út í hvaða aðferðir, leiðir eða hæfni viðmælendur nota til að veita forystu og leiða starfsmenn. Í stuttu máli pá nota viðmælendur mikið opin og óformleg samskipti, eru sýnileg og sýna starfsfólki áhuga. Miðlun upplýsinga er einnig mikilvægur páttur. Guðrún talaði um að hún notaði aðferðir pjónustu- og jafningjastjórnunar:

Detta eru náttúrulega jafningjar í peim skilningi að pau eru líka stjórnendur. Бau eru með svipað menntunarstig, pannig að samtal og jafningjastjórnun á parna við líka... Ein aðferð er líka í rauninni pjónustustjórnun. Að stjórnunarstarfið er í rauninni um leið pjónustustarf myndi ég segja gagnvart öllum starfsmönnum og kollegum í stjórnun.

Sigríður leggur einnig áherslu á að starfsfólk fái að njóta sín, samskipti séu opin og hún hrósar sínu fólki. Hún veltir líka fyrir sér hlutverki sínu sem bæði stjórnandi og leiðtogi:

Ég reyni bara að eiga svolítið opinskátt samstarf við starfsfólkið mitt pannig að pað setji sig líka í mín spor... Já, ég held einmitt að pað purfi að vera „little bit of both“ en ég er pá miklu frekar leiðtogi en stjórnandi. Ég held að leiðtogi leyfi fólkinu í kring um sig að vaxa og njóta sín.

Guðmundur leggur mjög mikið upp úr góðum samskiptum, hrósi, að sýna starfsfólki raunverulegan áhuga og er mjög sýnilegur og gengur í öll verk:

Dannig að ég hef lagt mikinn metnað í að tala við starfsfólkið til að vera vel inn í pví hvað pað er að gera... Já, ég er duglegur að hrósa. Ég nota hrós mikið, ég dreg mjög mikið fram pað sem að er jákvætt í starfinu. ..Ég tala aldrei um slæmu hlutina heldur tala ég alltaf um 
sóknarfæri, hvar við getum bætt okkur... Svo líka gef ég mig að starfsfólki, sem stjórnandi pá fer ég alltaf í kaffi með starfsmönnum og mat og reyni að tala við pá og reyni að sitja alltaf hjá sitt hvoru fólkinu í hverju hádegi... En svo er líka annað sem að ég hef lagt mig fram um sem stjórnandi, er að ég geng í öll verk.

Gott upplýsingaflæði og samskipti eru kjarninn í starfi Helgu. Hún tekur fram að í raun sé petta einfalt, en einfalt sé pó ekki alltaf auðvelt:

En pað er fyrst og fremst held ég petta upplýsingaflæði. Að stjórnendur tali skýrt, hvað er pað sem að peir vilja fá út úr vinnunni... og mér finnst petta bara vera að tala nógu oft við fólkið og nógu mikið.

Sigurður leggur áherslu á samstarf og að hans hlutverk sé að leiða hópinn:

Meginlínan hjá mér er að petta er samstarf og ég lít svo á að grundvallaratriðið er að allir gegna mikilvægu hlutverki og við erum öll í sama liðinu og pegar pú kemur á peim forsendum pá horfirðu svolítið á pig sem pann sem leiðir hópinn.

\subsection{Hæfniskröfur í ráđningarferlinu og nýliðapjálfun - „ljómandi fínt að pað var hæfnisnefnd"}

Viðmælendur töldu almennt að hæfniskröfur hefðu verið skýrar í atvinnuauglýsingunum og ráðningarferlinu. Mörg peirra tóku fram að auðvelt hefði verið að fylgja auglýsingunni og skrifa umsóknina út frá peim kröfum sem par komu fram. Í öllum tilfellum var um að ræða hæfnisnefndir og almennt eru viðmælendur ánægðir með hlutverk og vinnu hæfnisnefndanna. Um petta segir Guðrún:

Já, mér fannst pær alveg ágætlega skýrar og mér fannst pað ekkert vandamál að laga umsóknina að pví. Mér fannst ferlið aftur á móti ansi langt. Mér fannst ljómandi fínt að pað var hæfnisnefnd sem að spilaði parna nokkuð stórt hlutverk. Síðan voru lögð fyrir verkefni sem var bara ágætt að fara í gegnum.

Guðrúnu pótti ferlið langt og kemur pað heim og saman við upplifun annarra viðmælenda og við rannsóknir Berglindar Möller og Gylfa Dalmanns Aðalsteinsson (2014) og Hafsteins Dórs Haukssonar og Ómars H. Kristmundssonar (2019). Sigurði fannst hæfniskröfurnar skýrar og vel farið yfir pær í ráðningarviðtali:

Рað var náttúrulega horft til pátta eins og pátttökuí alpjóðasamstarfi og horft til pátta eins og umbótastjórnunnar og samskipta eða samstarfs og samskiptahæfni og pau viðtöl sem að ég fór í voru talsvert 
á peim nótum... Og síðan petta sígilda; stjórnunarreynsla, stefnumótun, áætlanagerð og allt petta. Öll boxin sem pú parft að tikka í til pess að geta verið í pví starfi sem að ég er í.

\subsubsection{Kröfur eftir rádningu - „ég fékek eitthvad skipunarbréf“}

pegar ráðning hefur farið fram á viðkomandi forstöðumaður að fá skipunarbréf samkvæmt 1. mgr. 38. gr. starfsmannalaga nr. 70/1996. Skipunar- eða erindisbréfin voru mjög misjöfn að umfangi og gæðum og ekkert samræmi virðist vera á milli ráðuneyta. Í sumum tilfellum komu fram kröfur til forstöðumannsins en í öðrum var einungis um að ræða skipunarbréf til fimm ára án pess að nokkuð væri vikið að verkefnum eða kröfum. Skipunarbréf Önnu var mjög innihaldsrýrt:

Ég fékk petta, pú ert ráðin í fimm ár, pakka pér fyrir.

Sama má segja um skipunarbréf Sigríðar en um pað segir hún:

Ég fékk eitthvað skipunarbréf sem var svo hallærislegt að ég bara, pað var bara eitthvað Times New Roman, 12 punkta letur og vísað í lögin.

Jón er hins vegar sáttur við skipunarbréfið og eftirfylgnina við ráðningu sína:

En mér pótti pað mjög skýrt en svo pegar ég var ráðinn pá tók ráðuneytið alveg að einhverju leyti utan um mig, sko ég fékk einhvern einn fund man ég... og ég fékk erindisbréf sem byggir að miklu leyti á lögum eða págildandi lögum og hérna svona pannig að já, alveg pokkalega. Jú, ég myndi segja að pað hafi bara verið prýðilegt.

Í öðrum tilfellum er skipunarbréf ítarlegt eins og í tilfelli Margrétar:

Petta er náttúrulega embætti, petta er ekki skilgreint sem einhver staða sem slík. Detta er embætti og pað kemur svona embættis- eða erindisbréf upp á margar blaðsíður par sem að ábyrgðin mín er skilgreind... petta er mjög ítarlegt og margar blaðsíður.

\subsubsection{Nýlidapjálfun forstödumanna - „ó, ert pú komin?"}

Enginn viðmælenda hafði fengið nýliðapjálfun og yfirleitt var ekki um neinn formlegan stuðning að ræða við forstöðumennina pegar peir hófu störf. Anna lýsir hér:

Fékk eitt reyndar viðtal svona mánuði eftir að ég byrjaði... Mætti ráđuneytisstjóranum á ganginum af pví að hann er náttúrulega, átti að vera minn næsti yfirmaður og hann sagði bara „ó, ert pú komin. Ég er upptekinn!“' Og svo labbaði hann bara burt... 


\section{STJÓRNMÁL \& \\ STJÓRNSÝSLA}

Kristín hefur sambærilega reynslu:

Ekki neitt. Фаð er engin handleiðsla pað er ekkert! ... Nei, pú getur googlað pað á netinu sem parft. Ég purfti að finna út úr pú veist kjaramálum og svona, pað var enginn sem að sagði velkomin til starfa, hér er linkur á starfsmannahandbókina sem á við um pig eða hér er mentorinn pinn eins og ef einhver er ráðinn inn til stofnana... Баð er ekkert svoleiðis! Ekkert! Рað er bara velkomin til starfa og svo er bara lokað hurðinni.

Gunnar sem hefur mikla reynslu sem stjórnandi og hefur tekið virkan pátt í félagsskap stjórnenda telur að pað sé engin nýliðapjálfun í boði fyrir stjórnendur:

Og pað held ég að sé svona sameiginleg reynsla... að pegar menn eru að hefja störf... að pað sé ákveðið tóm, peim sé varpað í djúpu laugina og svo purfi peir svolítið að finna út úr pví hvernig eigi að gera hlutina.

Viðmælendur voru sammála um að gott væri að fá nýliðapjálfun og margir töldu að hún væri algjörlega nauðsynleg. Spurð út í form nýliðapjálfunar var helst bent á að hafa mentor og kynningarfundi með ráðuneytinu. Kristín er með skýra tillögu um mentor:

Já, ég myndi klárlega segja annar forstöðumaður. Mín tillaga væri sú að maður gæti valið úr forstöðumönnum sem vildu vera mentorar.

Guðmundur taldi einnig pörf á skipulagðri nýliðafræðslu:

Раð parf að vera skipulagðari fræðsla fyrir nýliða sem að eru að taka við starfi forstöðumanna ríkisstofnana.

\subsection{Stjórnendastefna ríkisins og hæfniskröfur - „pað var einhver kynning“}

Til að stefna sé virk og komi að gagni purfa peir sem stefnan tekur til að pekkja hana og inntak hennar. Allir viðmælendur vissu um tilvist Stjórnendastefnu ríkisins en kynning má vera betri að mati viðmælenda. Einn viðmælenda sem hóf störf haustið 2019, eða eftir að stefnan var gefin út, hafði fengið mjög litla kynningu í sínu fagráðuneyti:

Já... ég veit ekki alveg hvort hún hafi verið kynnt. Рað hefur verið fjallað um hana og manns ábyrgð að kynna sér svona hluti sjálfur, líka sko. En hérna, jú, ég myndi nú alveg segja pað að hérna hún hafi verið kynnt. Рað gæti verið.

Sigurður hefur fengið stutta almenna kynningu en ekki neitt frekar: 
Ja, bara á pessum fundi sem að ég var að vitna í á sínum tíma. Ekkert annað.

Sigríður var boðuð á kynningu en komst ekki á fundinn og hefur ekki boðist kynning af öðru tagi.

Баð var einhver kynning en mig minnir að ég hafi ekki haft tök á pví að mæta á pann fund.

Afstaða viðmælenda í rannsókninni til stjórnendastefnunnar var hins vegar mjög jákvæð. peim fannst mikilvægt að hún sé komin fram og að innleiðingin verði tekin föstum tökum og gangi vel fyrir sig. Kristín bindur miklar vonir við stefnuna sem er lýsandi fyrir viðhorf viðmælenda í heild sinni:

Sko, mér líst mjög vel á pessa, stjórnendastefnuna og ég bind miklar vonir við að hún muni skila faglegri vinnubrögðum og ekki bara til okkar stjórnenda stofnana heldur líka til ráðuneytisins og pað verði meiri vensl og tengsl á milli og að pað verði pá líka eitthvað sem næst alla leið upp í stjórnsýslunni ekki bara forstöðumenn og að við séum pá öll að vinna að settum markmiðum.

•á kom fram hjá nokkrum viðmælendum mikil ánægja með vinnu Kjara- og mannauðssýslunnar og fjármála- og efnahagsráðuneytisins varðandi stjórnendastefnuna og ýmsar aðrar úrbætur sem unnið hefur verið að. Um petta segir Helga:

Mér finnst pað vera af hinu góða, pað er petta hvað mér finnst fjármálaráðuneytið vera að auka pessa eða pennan pátt starfsemi sinnar, sem sagt að hlúa að... Mér finnst pað mjög gott, petta er nýtt, petta er tiltölulega nýtt. Pannig að mér finnst petta mjög af hinu góða og er alveg sammála pessu sem að kemur fram parna.

\subsubsection{Körmynd stjórnenda - „endurspegla pessi lykilatridi“}

Kjörmynd stjórnenda (mynd 2) skiptist í prenns konar hæfni; leiðtogahæfni, samskiptahæfni og árangursmiðaða stjórnun og töldu viðmælendur hana vera lýsandi. Sumir töldu einstaka hæfnispætti mikilvægari en aðra en aðrir lögðu áherslu á heildarmyndina og samspil hæfnispáttanna. Í peim hópi er Anna sem telur alla hæfnispættina mikilvæga og að peir hafi áhrif hver á annan:

Ég myndi segja inn á við að pá purfa allir eða öll hólf að virka [allir hæfnispættir]. Ef pað er eitthvað áberandi sem að vantar að pá veikir pað mjög mikið alla heildina... Sem sagt ef samskiptin eru í molum en svakalega góðar áxtlanir að pá virkar petta ekki pannig að petta parf 
að vera allt að minnsta kosti í einhverjum lágmarks gæðum.

Sigurður telur að Kjörmyndin nái vel að lýsa helstu hæfnispáttum sem eru nauðsynlegir í stjórnendastarfi:

Nú er ég að horfa á stjórnendastefnuna, mér finnst hún svolítið endurspegla pessi lykilatriði par og pessi árangursmiðaða stjórnun. Pannig að mér finnst petta orð heilindi og pessi atriði sem eru talin parna upp, mér finnst pau harmónera ágætlega.

Guðmundur telur að Kjörmyndin nái sömuleiðis vel utan um hæfnispættina:

Hún dregur alveg ágætlega fram pessi stóru atriði sem að mér finnst skipta máli... Pannig að ég myndi segja leiðtogahæfnin og samskiptahæfnin, mér finnst pað skipta öllu máli í starfinu. Рað er líka talað náttúrulega um árangursmiðaða stjórnun og mér finnst pað koma kannski af sjálfu sér pegar að pú ert að rækta hina pættina.

\subsubsection{Leiðtogahaefni - „með hana pinu i fingrunum“}

Viðmælendur fjalla um leiðtogahæfni á ýmsan hátt og telja hana mjög mikilvæga. Fram kom hjá tveimur viðmælendum að leiðtogahæfni sé eitthvað sem viðkomandi annað hvort hefur eða hefur ekki. Sigríður er önnur tveggja sem álíta að leiðtogahæfni sé hæfileiki sem menn hafa eða ekki:

...en með leiðtogahæfni ég held að ég sé bara með hana pínu í fingrunum.... en ég er pá miklu frekar leiðtogi en stjórnandi.

Kristín er með svipuð viðhorf til leiðtogahæfni og Sigríður:

Leiðtogahæfnin hún er nú kannski, ég veit pað ekki, annaðhvort er maður með petta eða ekki.

Leiðtogahæfni finnst Margréti vera mjög vel lýst og dragi fram mikilvægustu pættina hvað hana og hennar starf varðar.

Ef að við byrjum á leiðtogahæfni að parna kemur náttúrulega bara nákvæmlega fram pað sem að mér finnst svo mikilvægt að vera með einhverja sýn á pað sem að pú ert að gera og stefnumótun sem að mér fannst vanta pegar ég kom hérna og er að bæta úr núna.

Guðmundur fjallar um að vera leiðtogi bæði inn á við og út á við og vera öflugur faglegur talsmaður stofnunarinnar: 
Jú, auðvitað parf maður að vera faglegur leiðtogi... og ég hef komið eða lagt mikla áherslu á að koma sterkt fram sem pannig leiðtogi... Mér finnst bara mikilvægt að við tjáum okkur sem leiðtogar... um faglegu málefnin og ég hef reynt að gera pað og starfsmenn kunna að meta pað.

\subsubsection{Samskiptahaefni - „ef hún er i molum að pá er allt bitt ónýtt“}

Viðmælendur eru sammála um mikilvægi hæfni í samskiptum. Pá leggja margir áherslu á að pað er alltaf hægt að bæta sig í samskiptum. Anna er stuttorð en mikilvægi samskipta er augljóst 1 hennar augum:

Samskiptahæfnin skiptir mestu máli inn á við og kannski gagnvart ráðuneytinu.

Guðrún er sama sinnis og telur samskiptahæfni vera algjöra lykilhæfni:

... ef að pú hefur ekki samskiptahæfnina, ef hún er í molum að pá er allt hitt ónýtt líka.

Kristín leggur áherslu á eins og margir aðrir að pað er alltaf hægt að proska og bæta sig í samskiptum:

maður parf að proska rosalega mikið sjálfur og með sjálfum sér og auðvitað að reka sig á.

Раð skiptir máli hvaða aðferðum er beitt í samskiptum og mismunandi aðferðir henta við mismunandi úrlausnarefni. Pegar leiðrétta parf starfsmann eða benda honum á að hann purfi að bæta sig í starfi pá leggur Guðmundur áherslu á jákvæða sálfræði:

Pá er ég frekar að eiga uppbyggilegt samtal við pá pannig að peir fari út og ætli að gera betur. Pannig að ég nota jákvæða sálfræði bæði á starfsfólk og... mjög mikið.

\subsection{4 Árangursmiðuð stjórnun - „er náttúrulega gríðarlega mileilvagt“}

Minnst var rætt um pennan pátt í viðtölunum. Skýringin gæti verið sú að sumum viðmælendum fannst pessir pættir vera tæknilegir pættir og að sumu leyti sjálfsagðir. Ýmislegt fróðlegt kom pó fram, ekki síst vangaveltur um hvort viðkomandi væri sterkur í einstökum páttum eða pyrfti að bæta sig í einhverjum peirra. Margrét tengir árangursmiðaða stjórnun við pá pjónustu sem stofnunin á að veita.

Áætlanagerð og forgangsröðun, petta er náttúrulega gríðarlega mikilvægt að hérna að við séum að sinna peirri pjónustu sem að lögin segja 
til um... skilvirk stýring verkferla finnst mér líka góður punktur parna inn í og petta er einmitt eitthvað sem að við erum að vinna í núna í okkar framtíðarstefnu að setja fram.

Nýsköpun er einnig dregin fram í máli Önnu:

Mér finnst petta allt vera frekar lógísk og mikilvæg atriði. Ég myndi segja til dæmis að nýsköpun hefur svona ekki átt neitt stóran sess held ég í svona opinberum stofnunum. Ég held að hún mætti vera sterkari og er svolítið hreyfiafl til breytinga.

Margrét nefnir líka að gæta parf hagkvæmni í rekstri eins og tilgreint er í kjörmyndinni og orðar pað á einfaldan og skýran hátt:

Svo náttúrulega hagkvæmni í rekstri sem að náttúrulega skiptir öllu máli, að jafnan parf að ganga upp. Peningarnar sem koma inn purfa að passa við peningana sem að fara út.

\subsubsection{Heilindi - „ganga dálítid út á pad ad vidurkenna mistök i starfi“}

Sammerkt er að viðmælendur töldu heilindi mikilvæg í starfi. Nokkrir sögðu að heilindi snúist um að vera trúr fagráðuneytinu en fleiri voru með víðara sjónarhorn og töluðu um heilindi gagnvart starfinu, samstarfsfólkinu og gagnvart sjálfum sér. Sigríður er í fyrri hópnum:

Ég held að pað sé til dæmis heilindi... ég sýni bæði yfirboðurum mínum og ráđuneytinu mikla hollustu og ég tel pað bara lykilinn til árangurs að koma hreint og beint fram.

Kristínu finnst orðið heilindi vera stórt og mikið, en einnig fallegt orð:

Mér finnst líka petta orð heilindi, mér finnst petta mjög fallegt orð. Mér finnst pað eiga vel við parna miðjuna. Mér finnst petta vel valið... Já, mér finnst pað mjög. Sko, ég held að pað eigi bæði við heilindi gagnvart sjálfum sér að maður starfi eftir bestu getu en líka heilindi gagnvart starfsmönnum og heilindi gagnvart ríkinu.

Guðmundur talar um sanngirni, að vera trúr sinni sannfæringu og að pora að viðurkenna mistök:

Já, ég allavega heilindin sem að ég myndi skilja er að vera samkvæmur sjálfum pér, koma fram af sanngirni við hérna allt og alla. Pú líka ert trúr pinni sannfæringu en heilindi pýða líka að pegar pú hefur rangt 
fyrir pér að pá á maður að vera fyrstur til að viðurkenna að maður hefur rangt fyrir sér... og heilindi ganga dálítið út á pað að viðurkenna mistök í starfi.

\subsection{Samskipti við fagráđuneyti - „ég hrósa starfsfólkinu í ráđuneytinu“}

Samskipti við fagráđuneytin komu víða til tals. Á sama tíma og verið var að vinna úr viðtölunum birti Félag forstöðumanna ríkisstofnana niðurstöður könnunar sem lögð hafði verið fyrir félagsmenn. Samkvæmt henni skortir mjög á endurgjöf og stuðning fagráðuneytanna. Innan við 5\% forstöðumanna höfðu fengið endurgjöf (Félag forstöðumanna ríkisstofnana 2020). Niðurstöður úr könnuninni eru mjög í takt við upplifun viðmælenda í pessari rannsókn; samstarfi af hálfu fagráðuneytanna er almennt ábótavant.

Erfitt rekstrarumhverfi hefur mikil áhrif á samskipti við ráðuneytin eins og eftirfarandi ummæli vitna um. En prátt fyrir neikvæð orð pá minnir einn viðmælandi á að hann og ráðuneytið séu í sama liðinu:

Dú einhvern veginn hefur ekkert svigrúm í neitt pannig pví pú hefur ekki rekstrarframlagið. Pannig að t.d. eftirfylgni áætlana... hvað ætlar ráðuneytið raunverulega að vera vont við mann? ...En ég kýs að líta á petta fólk sem samstarfsfólk mitt, petta eru ekki andstæðingar mínir, mér finnst pað koma betur út.

Forstöðumenn eru ekki frábrugðnir öðru starfsfólki og peir purfa athygli, hvatningu og hrós. Lítið virðist vera um pað:

Í eitt skiptið sem ég tala við ráðuneytisstjórann pá segir hann pessa frægu setningu, ,jú, ég get ekkert annað gert en kannski hlustað á pig““, og ég bara... Pá féllust mér allar hendur, ef ég hefði bara purft að láta hlusta á mig pá hefði ég bara farið til sálfræðings sko!

Samskipti við fagráðuneyti voru slæm að mati pessa forstöðumanns en jákvæð samkvæmt öðrum:

Ég hrósa líka, ég hrósa starfsfólkinu í ráđuneytinu, ég hika ekki við að senda póst á ráðherra og segja: „Mér finnst pið vera að gera hlutina vel““.

Síðastliðin ár hefur ýmistlegt farið batnandi. Lykillinn að góðum samskiptum liggur ekki eingöngu hjá ráðuneytunum heldur líka hjá forstöðumönnunum.

\subsection{Ráđleggingar til nýrra forstöðumanna - „vera heiðarlegur, réttlátur og vera eins og manneskja“}

Mikilvægi góðra samstarfsmanna, samvinnu og samskipta kemur fram hjá öllum viðmælendum pgar pau eru spurð um ráðleggingar til nýrra forstöðumanna: 
Ná sér í gott tengslanet strax meðal annarra stjórnenda og ekki hika við að ganga á öxlunum á fólki. Mér finnst ég vera að gera pað alla daga að nýta styrk samstarfsfólks.

Ráðlegging Önnu er skýr:

Já, ég held ég myndi segja að sinna starfsmannamálum...

Kristín leggur áherslu á að finna sér mentor og að hafa trausta samstarfsmenn:

Ég myndi ráðleggja peim að finna sér mentor.

Helga talar um mikilvægi góðra samskipti, byggja upp traust og nýta sér teymisvinnu.

Byggja upp traust í stjórnendahópnum, pað er mjög mikið atriði, pannig að fólk vinni vel saman. Ég hef ofurtrú á teymis- og samvinnu... pað er enginn eyland neins staðar eins og petta var.

Gunnar sagði:

Pannig að bara vera heiðarlegur, réttlátur og vera eins og manneskja svona sem að pú ert og gera fólki pað ljóst til hvers er ætlast og hvers er vænst og hrósa.

\subsection{Forysta í heimsfaraldri - „vera til stađar og vera á gólfinu“}

Eðlilega bar Covid á góma í viðtölunum. Mikið reynir á forystuhæfileika í erfiðum aðstæðum og pví forvitnilegt og upplýsandi að kanna viðhorf og viðbrögð við faraldrinum.

Covid hefur aukið álag og seinkað ýmsum verkefnum, ekki síst hjá peim sem voru аð hefja skipulagsbreytingar. Hins vegar voru ekki miklar áhyggjur af áhrifum Covid til lengri tíma litið. Sigurður var að hefja skipulagsbreytingar og sér hættumerki í pví að faraldurinn beri hann af leið:

Ég var að breyta skipuritinu, kynna pað í enda janúar, breytingin tók gildi 1. mars og Covidið er í gangi á sama tíma og við erum með skipulagsbreytingar... og síðan er pví bara ýtt til hliðar og verkefnin fara að snúast um eitthvað allt annað.

Stofnanirnar purftu að bregðast við, skipta upp starfseminni, gera fólki kleift að vinna heima og í sumum tilfellum að taka við auknum og nýjum verkefnum. Helga lýsir áskorunum sem pví fylgdu á eftirfarandi hátt:

Petta var alveg svakaleg áskorun í vor að tæknivæða alla og koma peim heim, pannig að pað gæti unnið heima og um leið innleiða alveg fullt 
af nýjum verkefnum og fá nýtt fólk í vinnu og kenna pví og pjálfa, sko. petta er búið að vera... petta ár er búið að vera mikill rússíbani í lífi [stofnunarinnar], pað verður að segjast eins og er.

Heimsfaraldurinn hefur gert kröfu á tvo af viðmælendunum um hæfni í samskiptum við fjölmiðla, sem pau höfðu ekki purft að hugsa um áður. Um petta segir Helga:

Ég var mjög óvön pessu fjölmiðlafári sem að var í kring um petta líka, en pað var fyrst og fremst skóli fyrir mig.

Erfiðar áskoranir geta verið jákvæðar og fram kemur hjá nokkrum viðmælendum að ýmsir pættir hafi styrkst, til dæmis pættir eins og samheldni og samvinna. Faraldurinn kallar á ólíka forystuhæfileika, segir Gunnar:

Að leiða fólk í gegnum pessa óvissutíma. Og vera til staðar og vera á gólfinu og ganga með fólkinu og leiða pað.

Guðmundur hefur líka séð jákvæðu hliðarnar á Covid og samskipti við fagráðuneytið hafa orðið meiri og betri en áður:

... sem betur fer pá má kannski segja að á tímum Covid að pá hafa samskipti allavega [stofnunarinnar] og ráðuneytisins aukist til muna... mér finnst aðgangurinn að ráðuneytinu miklu betri núna.

\section{Umræða}

Rannsóknin leitaðist við að svara fjórum rannsóknarspurningum: Hvað reynir mest á i starfi nýrra stjórnenda bjá rikinu? Fengu nýir stjórnendur fraðslu eða pjálfun pegar pau bófu störf? Telja nyir stjórnendur à pjálfun sé mikilvag fyrir nýja stjórnendur? Hver eru vidhorf nýrra stjórnenda til haefniskrafna sem fram koma i Stjórnendastefnu rikisins?

Varðandi hvað reynir mest á í starfi nýrra stjórnenda hjá ríkinu pá gefa niðurstöður til kynna að störf stjórnenda séu fjölbreytt og reyni á margslungna hæfni peirra. Mörg og fjölbreytt verkefni eru í mannauðsmálum. Samskiptahæfni er mjög mikilvæg samkvæmt viðmælendunum sem er í góðu samræmi við fyrri rannsóknir (Barrett 2006; Inga Jóna Jónsdóttir \& Kristrún Friðriksdóttir 2019; Liddle 2017).

pví er samræmi í niðurstöðum pessarar rannsóknar og annarra sem lúta að kröfum til stjórnenda ríkisstofnana. Fyrri rannsóknir sýna að kröfur hafi aukist í kjölfar nýskipunar í ríkisrekstri (Bára Sif Sigurjónsdóttir 2020; Ómar H. Kristmundsson 1999), vegna breytts umhverfis og tækninýjunga (Agarwal 2018) og breytta krafna um stjórnendahæfni (Gylfi Dalmann Aðalsteinsson 2010) auk pess eru stofnanir metnar og verðlaunaðar kerfisbundið af stéttarfélögum (Sameyki e.d.). Auknar kröfur eru um skilvirkni og framleiðni (Ríkisendurskoðun 2011; Viðskiptaráð Íslands 2020).

Einnig má segja að rannsóknin varpi ljósi á að stjórnun hefur breyst frá pví að vera 
skipandi yfir í samstarf og samvinnu eins og aðrar rannsóknir sýna (Chulwoo 2009; Chin 2015). Opinber rekstur krefst pess að hugað sé að félagslegum, rekstrarlegum og pólitískum markmiðum (Gunnar Helgi Kristinsson 2007; Kellerman \& Webster 2001) sem og innri páttum eins og hagkvæmni, aukinni skilvirkni, mannauðsmálum og stefnumótun (Solomon o.fl. 2016).

Viðmælendur eru sammála pví að til að ná árangri í starfi stjórnenda purfi peir að búa yfir félagslegri hæfni, geta sýnt samlíðan, pekkja sjálfa sig, gildi sín og skoðanir og geta átt opin og heiðarleg samskipti (Chin 2015), haft færni til að efla samstarf, samvinnu og að skapa góðar vinnuaðstæður (Inga Jóna Jónsdóttir 2012).

Kellerman $(2007$; 2013) hefur fjallað um hið sérstaka hlutverk stjórnenda hjá hinu opinbera, p.e. pjónusta við pegnana. Viðmælendur eru mjög meðvitaðir um pann pátt í starfi sínu en rekstrarumhverfið er krefjandi páttur með niðurskurði fjárveitinga og skorti á mannskap. Í minni stofnunum sjá forstöðukonur og -menn um rekstur og fjármál, mannauðsmál og faglega stjórnun en stjórnendur stærri stofnana kljást einnig við pröngan rekstrarramma og purfa að vera sérfræðingar á mörgum sviðum. Hin nýja stjórnendastefna og hæfniskröfur sem par eru taldar fram falla pví vel að sjónarmiðum viðmælenda um hvaða hæfni nýir stjórnendur purfa að búa yfir.

Varðandi spurninguna um hvort viðmælendur fengju nýliðapjálfun pá kemur í ljós að peir töldu sig fá litla sem enga pjálfun, leiðbeiningar eða kennslu pegar pau tóku við starfi forstöðumanna. Annarri rannsóknarspurningunni um pjálfun er pví afdráttarlaust svarað neitandi. Viðmælendur voru sammála um nauðsyn pess að forstöðumenn fái nýliðapjálfun, einnig peir sem hafa stjórnunarreynslu. Hugsanlega má rekja skort á nýliðapjálfun til veikari vinnustaðamenningu (एórhallur Örn Guðlaugsson o.fl. 2018). Parna virðist vera gjá milli stefnunnar og hvernig henni er fylgt eftir. Einnig kemur fram að æðstu stjórnendur ráðuneyta séu óaðgengilegir. Tekið skal fram að eingöngu er byggt á tíu viðtölum.

Viðhorf peirra nýju stjórnenda sem rætt var við til stjórnendastefnu ríkisins, sem var gefin út sumarið 2019 (Stjórnarráð Íslands 2019b) voru almennt jákvæð. Pó ber að nefna að heimsfaraldurinn hefur haft áhrif á innleiðingu stefnunnar. Bjartsýni ríkir meðal viðmælenda um að stjórnunarstefnan muni skila árangri. Stjórnendastefnan er ítarleg og byggist á að stjórnandinn sýni heilindi í starfi. Hæfnispættir sem lagðir eru til grundvallar eru leiðtogahæfni, samskiptahæfni og árangursmiðuð stjórnun og fannst viðmælendum pað endurspeglast í starfi peirra. Viðmælendur töldu allir að heilindi væru grundvallaratriði í starfi stjórnandans og styður pað við rannsóknir sem sýnt hafa fram á mikilvægi peirra (Palanski \& Yammarino 2007).

Rannsóknin varpar ljósi á ýmsa aðra pætti. Mikilvægt er að mati viðmælenda að gott samband sé við fagráðuneyti og að ákveðinn tengiliður sé í ráðuneytinu. Verulega skortir á góðan stuðning frá ráðuneytunum sem er í samræmi við nýlega könnun Félags forstöðumanna ríkisstofnana (2020). •ó eru, að mati nokkurra viðmælenda, merki um að Covid-19 hafi aukið og bætt pessi samskipti.

Benda má á prjá mikilvæga hæfnispætti sem fram komu í viðtölunum en eru ekki í stjórnendastefnunni sem vert er að skoða nánar. Đað eru pættirnir: Virk hlustun, lausn ágreiningsmála og teymisvinna. 
Virk hlustun hefur fengið aukna athygli síðustu árin en lengi vel var lítið hugað að mikilvægi hennar fyrir stjórnendur (Alvesson \& Sveningsson 2003) og nýleg íslensk rannsókn staðfestir mikilvægi virkrar hlustunar í starfi stjórnenda (Inga Jóna Jónsdóttir \& Kristrún Friðriksdóttir 2019)

Samskipti hafa óhjákvæmilega í för með sér ágreining par sem fólk er ekki alltaf sammála um leiðir, markmið og stefnu (Lawless \& Trif 2016). Viðmælendur kalla eftir pjálfun í lausn ágreiningsmála sem er í samræmi við pá hæfnispætti sem rannsóknir sýna að eru mikilvægir (Liddle 2017).

Teymisvinna er ekki nefnd í kjörmynd stjórnenda en áhersla á teymisvinnu hefur aukist mikið síðustu ár og áratugi hjá opinberum stofnunum (Chin 2015). Nokkrir viðmælendur töldu teymisvinnu grundvallarpátt í sinni stjórnun. Skoða mætti að bæta hæfni í teymisvinnu við hæfnispættina.

Stjórnendur hjá ríkinu eru í krefjandi störfum og rannsóknin sýnir að viðmælendurnir purfa að búa yfir fjölbreyttri hæfni, bæði á sviði stjórnunar og forystu. Stjórnendastefna ríkisins er vegvísir og til mikilla bóta að mati viðmælenda sem mikilvægt er að innleiða á farsælan og ákveðinn hátt. Jákvæðni var áberandi í orðum peirra og fasi sem er mikilvægt veganesti við innleiðingu stjórnendastefnunnar.

\section{Heimildir}

Agarwal, P. (2018). „Public administration challenges in the world of AI and bots“, Public Administration Review 78(6), 917-921.

Alvesson, M. og Sveningsson, S. (2003). „Managers doing leadership: The extra-ordinarization of the mundane“, Human relations 56(12), 1435-1459.

Barrett, D. J. (2002). „Change communication: Using strategic employee communication to facilitate major change", Corporate Communication: An International Journal 7(4), 219-231.

Barrett, D. J. (2006). Leadership communication. New York, NY: McGraw-Hill.

Bára Sif Sigurjónsdóttir (2020). Eru forstödumenn opinberra stofnana fagstjórnendur? (meistararitgerð). Reykjavík: Háskóli Íslands. Sótt af http://hdl.handle.net/1946/35161

Bell, E., Bryman, A. og Harley, B. (2018). Business research methods (5. útgáfa). New York, NY: Oxford University Press.

Berglind Möller og Gylfi Dalmann Aðalsteinsson (2014). „Samanburður á ráðningarferli við embættisveitingar á Íslandi fyrir og eftir efnahagshrunið“, Stjórnmál \& stjórnsýsla 10(2), 249-272. Sótt af http://hdl.handle.net/1946/23381

Borins, S. (2001). „Encouraging innovation in the public sector“, Journal of Intellectual Capital 2(3), 310 319. https://doi.org/10.1108/14691930110400128

Boyne, G. A. (2002). „Public and private management: What's the difference?“, Journal of Management Studies 39(1), 97-122.

Buelens, M. og Van den Broeck, H. (2007). „An analysis of differences in work motivation between public and private sector organizations“, Public Administration Review 67(1), 65-74.

Chin, R. J. (2015). „Examining teamwork and leadership in the fields of public administration, leadership and management", Team performance management 21(3/4), 199-216. https://doi.org/10.1108/ TPM-07-2014-0037

Chulwoo, K. (2009). „Developing effective leadership skills“, Public Administration Review 69(3), 547-549.

Corbin, J. og Strauss, A. (2014). Basics of qualitative research: Techniques and procedures for developing grounded theory. Thousand Oaks, CA: Sage. 


\section{STJÓRNSÝSLA}

Félag forstöðumanna ríkisstofnana (2020). Niðurstöður könnunar um starfsviðtöl o.fl. Sótt af https:// ffr.is/nidurstodur-konnunar-um-starfsvidtol-o-fl/

Funck, E. og Karlsson, T. (2020). „Twenty-five years of studying new public management in public administration: Accomplishments and limitations", Financial Accountability \& Management 36(4), $347-375$.

Gunnar Helgi Kristinsson (2014). Hin mörgu andlit lýdrađis: pátttaka og vald á sveitastjórnarstigi. Reykjavík: Háskólaútgáfan.

Gunnar Helgi Kristinsson (2007). Íslenska stjórnkerfið (2. útgáfa). Reykjavík: Háskólaútgáfan.

Gylfi Dalmann Aðalsteinsson (2005). „Fagleg ráoning - embættisveitingar hjá hinu opinbera í ljósi mannauðsstjórnunar" í Ingjaldur Hannibalsson (ritstjóri), Rannsóknir i félagsvísindum VI. Viðskipta- og hagfrađideild (bls. 173-187). Reykjavík: Félagsvísindastofnun Háskóla Íslands.

Gylfi Dalmann Aðalsteinsson (2006). „Geta aðferðir mannauðsstjórnunar aukið gæði ráðninga hjá hinu opinbera?", Stjórnmál \& stjórnsýsla 2(1), 2-10. Sótt af http://hdl.handle.net/1946/8925

Gylfi Dalmann Aðalsteinsson (2010). „Starfsumhverfi hins opinbera: Hlutverk stjórnenda og viðhorf starfsmanna“, Stjórnmál \& stjórnsýsla 6(2), 63-78. Sótt af http://hdl.handle.net/1946/9144

Hafsteinn Dór Hauksson og Ómar H. Kristmundsson (2019). „Reynsla af ráðgefandi hæfnisnefndum“, Tímarit Lögréttu 2019(15). Sótt af https://www.ru.is/media/logretta/Reynsla_af_radgefandi_haefnisnefndum.pdf

Hagstofa Íslands (e.d.). „Hve margir heita?“ Sótt af https://hagstofa.is/talnaefni/ibuar/faeddir-ogdanir/nofn/

Hartley, J. (2018). „Ten propositions about public leadership“, International Journal of Public Leadership 14(4), 202-217.

Heifetz, R. A. og Linsky, M. (2017). Leadership on the line: Staying alive through the dangers of change. Boston, MA: Harvard Business School Press.

Inga Jóna Jónsdóttir (2012). „Starfspróun millistjórnenda í opinberri starfsemi“, Vorráostefna Vidskiptafradistofnunar Háskóla Íslands 23. mars 2012. Sótt af http:// hdl.handle.net/1946/12522

Inga Jóna Jónsdóttir og Kristrún Friðriksdóttir (2019). „Active listening: Is it the forgotten dimension in managerial communication?", International Journal of Listening 34(3), 178-188. Sótt af https://doi. org/10.1080/10904018.2019.1613156

Kellerman, B. (2013). „Leading questions: The end of leadership - redux“, Leadership 9(1), 135-139.

Kellerman, B. (2007). „What every leader needs to know about followers“, Harvard Business Review 85(12), 84-91.

Kellerman, B. og Webster, S. W. (2001). „The recent literature on public leadership: Reviewed and considered“, Leadership Quarterly 12(4), 485-514.

King, A. S. (1990). „Evolution of leadership theory“, Vikalpa 15(2), 43-54.

Kotter, J. P. (1996). Leading change. Boston, MA: Harvard Business School Press.

Kotterman, J. (2006). „Leadership versus management: What's the difference?“, The Journal for Quality and Participation 29(2), 13-17. Sótt af https://www.proquest.com/ scholarly-journals/leadershipversus-management-whats-difference/docview/219091679/se-2?accountid=135705

Lawless, J. og Trif, A. (2016). „Managing interpersonal conflicts at work by line managers“, Irish Journal of Management 35(1), 74-87. Sótt af http://dx.doi.org/10.1515/ijm-2016-0005

Lee, Y., Chen, P. og Su, C. (2020). „The evolution of the leadership theories and the analysis of new research trends“, International Journal of Organizational Innovation 12(3), 88-104. Sótt af https:// search.proquest.com/scholarly-journals/evolution-leadership-theories-analysis-new/docview $/ 2334751436 /$ se-2? accountid $=135705$

Liddle, D. (2017). Managing conflict. Croydon: CIPD.

Mankin, D. (2009). Human resource development. New York, NY: Oxford University Press.

Mintzberg, H. (2009). Managing. San Francisco, CA: Berrett-Koehler.

Mintzberg, H. og Caldwell, C. (2017). „Leadership, “communityship,” and “the good folk”““, International Journal of Public Leadership 13(1), 5-8. Sótt af https://doi.org/10.1108/IJPL-12-2016-0053 


\section{STJÓRNSÝSLA}

Mintzberg, H. og Gosling, J. (2002). „Educating managers beyond borders“, Academy of Management Learning \& Education 1(1), 64-76. Sótt af https://doi.org/10.5465/AMLE.2002.7373654

Mumford, M. D., Todd E. M., Higgs, C. og McIntosh, T. (2017). „Cognitive skills and leadership performance: The nine critical skills“, The Leadership Quarterly 28(1), 24-39. Sótt af https://doi.org/ 10.1016/j.leaqua.2016.10.012

Ómar H. Kristmundsson (ritst.) (1999). Starfsumbverfi ríkisstarfsmanna við aldabvörf. Sótt af https://stjornsyslustofnun.hi.is/sites/stjornsyslustofnun.hi.is/ files/gudruney/starfsumhverfi-1.pdf

Ómar H. Kristmundsson (2009). „Eru ráðninganefndir gagnleg leið við skipanir æðstu embættismanna?" í Halldór S. Guðmundsson og Silja Bára Ómarsdóttir (ritstj.), Rannsóknir i félagsvísindum X (bls. 241-351). Reykjavík: Félagsvísindastofnun Háskóla Íslands.

Palanski, M. og Yammarino, F. (2007). „Integrity and Leadership“, European Management Journal 25(3), 171-184.

Ríkisendurskoðun (2011). Skýrsla til Alpingis. Mannauðsmál ríkisins - 2. Stefna stjórnvalda og staða mannauðssmála ríkisins. Sótt af https://rikisendurskodun.is/wp-content/uploads/2016/01/111027_LOKAEINTAK.pdf

Ríkisendurskoðun (2014). Skýrsla til Alpingis. Skýrsla um eftirfylgni. Mannaudsmál ríkisins - 2. Stefna stjórnvalda og staða mannaudssmála ríkisins. Sótt af https://rikisendurskodun.is

Ríkisendurskoðun (2017a). Skýrsla til Alpingis. Eftirfylgni. Mannaudsmál rikisins - 2. Stefna stjórnvalda og stada mannaudssmála ríkisins. Sótt af https://rikisendurskodun.is/wp-content/uploads/2017/04/ IEU-Mannaudsmal2.pdf

Sameyki (e.d.). „Helstu niðurstöður - allar stofnanir“. Sótt af https://www.sameyki.is/kannanir/stofnun-arsins-2020/helstu-nidurstodur-allar-stofnanir/

Solomon, I. G., Costea, C. og Nita, A. M. (2016). „Leadership versus management in public organizations", Economics, Management and Financial Markets 11(1), 143-151. Sótt af https://search. proquest.com/scholarly-journals/leadership-versus-management-public-organizations/docview $/ 1782998705 /$ se-2?accountid $=135705$

Stjórnarráð Íslands (e.d.). „Mannauðsmál ríkisins“. Sótt af https://www.stjornarradid.is/verkefni/ mannaudsmal-rikisins/

Stjórnarráð Íslands (2019). „Ný stjórnendastefna ríkisins: Bætt færni stjórnenda og aukinn samfélagslegur ávinningur". Sótt af https://www.stjornarradid.is/default.aspx?pageid=e5cf150d-33a7-11e680c7-005056bc217f\&newsid=55418c1b-97fc-11e9-9443-005056bc4d74

Stjórnarráð Íslands (2019b). „Stjórnendastefna ríkisins“. Sótt af https://www.stjornarradid.is/library/ 02-Rit--skyrslur-og-skrar/Stj\%c3\%b3rnendastsefna $\% 20$ loka $\%$ c3\%batg $\%$ c3\%a1 fa $\% 20062019 \% 20$ (002).pdf

Viðskiptaráð Íslands (2020). Hið opinbera: Meira fyrir minna. Sótt af https://vidskiptarad.cdn.prismic.io/vidskiptarad/733dbdcb-8727-43f3-8913-579c464987fb_hid_opinbera_2020.pdf

Yorks, L. (2005). Strategic buman resource development. Mason, OH: South-Western, Thompson.

Yukl, G. (2012). „Effective Leadership Behavior: What We Know and What Questions Need More Attention", The Academy of Management Perspectives 26(4), 66-85.

pórhallur Örn Guðlaugsson, Gylfi Dalmann Aðalsteinsson og Svala Guðmundsdóttir (2018). „Samanburður á vinnustaðamenningu stofnana og fyrirtækja“, Stjórnmál \& stjórnsyisla 14(3), 205-226. Sótt af https://doi.org/10.13177/irpa.a.2018.14.3.3 